\title{
The Effects of Virtual and Computer Based Real Laboratory Applications on the Attitude, Motivation and Graphic Skills of University Students
}

\author{
Uğur Sari ${ }^{\mathrm{a}}$, H. Miraç Pektaş ${ }^{\mathrm{a}}$, Harun Çelik ${ }^{\mathrm{a}}$, Talip Kirindi ${ }^{\mathrm{a}}$ \\ Corresponding author: Uğur Sarı (ugursari@kku.edu.tr) \\ ${ }^{a}$ Kırıkkale University, Education Faculty, Department of Mathematics and Science Education, Turkey
}

Keywords: physics laboratory, computer based laboratory, computer simulations, graphical skills, motivation, attitude

International Journal of Innovation in Science and Mathematics Education, 27(1), 1-17, 2019.

\begin{abstract}
In recent years, experience of students in technology-equipped laboratories has been seen as an effective way to teach and learn physics. In this sense, experiments and demonstrations using computer based data collection systems and simulations that allow students to design their own virtual experiments in the physics laboratory come into prominence. In this study, the usage of computer based laboratory and virtual laboratory applications in the physics laboratory are discussed. In this context, the effects of computer based laboratory applications and virtual laboratory applications on students' graph drawing, understanding and interpretation skills, attitudes towards the physics laboratory and motivation for learning science were investigated. Sixty university students participated in the pre-test post-test semi-experimental design study. While the control group carried out experiments on the laws of motion with computer based laboratory, the experimental group performed the same experiments with virtual laboratory applications. The data of the study were collected through attitude scale, motivation scale and graph drawing, understanding and interpretation test. Independent sample t-tests were used in the analysis of the data. The findings show that computer based laboratory practices are more effective in the development of students' ability to draw, understand and interpret graphics than virtual laboratory applications. It has been determined that both computer based laboratory and virtual laboratory applications have a positive effect on students' attitudes and motivations. Also, computer based laboratory applications were found to be more effective in increasing students' motivation levels for communication, collaborative work, and participation than virtual laboratory applications. The findings of the study suggest that computer based laboratory applications in physics laboratories are more effective than virtual laboratory applications.
\end{abstract}

\section{Introduction}

When we look at technology-assisted science education research, computer use is mostly seen as computer-based laboratory (CBL) and virtual laboratory (VL) applications (Daineko, Dmitriyev, \& Ipalakova, 2017; Duman \& Avc1, 2016; Liu, Wu, Wong, Lien, \& Chao, 2017). CBL is the system using for conducting experiments, collecting and analyzing data and providing graphical systems. They include several modelling and data acquisition tools like computer, sensors and timer (Amrani \& Paradis, 2010; Liu et al., 2017). The richness of CBL applications and modelling tools are very important in physics education (Bozkurt, 2008). Especially with CBL applications, students can create graphs which are moving and changing continuously through software which is transferred to computer by using sensors and receivers. Physical parameters such as position, speed, acceleration, force and temperature can be measured and shown to students using such software. Therefore, the waste of time in the collection of data and in drawing the graphs is eliminated (Bozkurt, 2008; Tortosa, 2012). Thus, 
students can focus their attention in explaining the relationship among the data variables (Liu et al., 2017). VL applications are computer modelling tools with visualizations, animations and simulations that present theoretical or simplified models of real life processes and phenomena (Mcdonald, 2016; Smetana \& Bell, 2012). Despite not providing real equipment, experimental data generated by VL are empowered by mathematical models. Thus, at the end of the virtual experiment, students are provided with reasonable experimental data for data processing and analysis at an advanced level (Daineko et al., 2017). Especially in recent years, the use of computer simulations as technological products to increase the effectiveness of physics education is in the foreground (Jaakkola, Nurmi, \& Veermans, 2011; Rutten, van Joolingen, \& Van der Veen, 2012; Rutten, Van der Veen, \& van Joolingen, 2015; Daineko et al., 2017).

The rapid spread of technology in schools and integration of it into teaching reshaped the interaction of teachers, students, curricula and technologies, and eventually transformed the learning environment (Wu, Chang, \& Guo, 2009). This process, which makes the use of computer technology in teaching and learning applications important, has increased the motivation and meaningful learning of students for physics learning (Berrett, 2012). So, it has been reshaped in laboratories as an important learning environment in physics teaching, and technology has been used in laboratories (Chiu, DeJaegher, \& Chao, 2015). The use of technology in science laboratories provides useful opportunities for students who can participate in high-budget, dangerous and complex experiments which are difficult to realize (Akçayır, Alçayır, Pektaş \& Ocak, 2016). Research on the use of technology in science laboratories has shown that it yields positive results (Olympiou \& Zacharias, 2013; Trundle \& Bell, 2010). On the other hand, some studies reported that the use of educational technology did not significantly affect the effectiveness of science laboratories (Klahr, Triona, \& Williams, 2007; Wiesner \& Lan, 2004).

Learning has become richer and more permanent with the inclusion of technological tools such as projection and smart boards in the classroom as well as in science laboratories. These applications increase student motivation, enable students to learn at their own pace and combine computer technology with self-learning principles (Uşun, 2004). Thus, technology allows students to access educational resources virtually from anywhere at any time (Zhang, de Pablos, \& Xu, 2014). The theories and approaches that are based on the curriculum have been integrated into the technology, too. There are various student-cantered, active learning methods and techniques suitable for constructivist learning environments. One of the most popular applications supporting these methods and techniques is the use of simulations (Azar \& Aydın-Şengüleç, 2011; Jaakkola \& Nurmi, 2008; Jaakkola et al., 2011; Rutten et al., 2012). Some studies have shown that simulations are effective ways to increase students' perceptions and interests and to encourage students' cognitive structures (Rutten et al., 2012). It can be said that learning environments enriched by CBL and VL applications contribute to physics teaching. However, teachers' use of technology in learning environments may vary because the physical and technological equipment of schools and the effects of technology on learning products may change.

Several empirical studies were carried out on the advantages of CBL and VL. Kaberman and Dori (2009) showed that CBL applications provide significant improvement in students' higher-order thinking skills. Gunhaart and Srisawasdi found the improvement of learners' indepth understanding of scientific concepts with the assistance of CBL in physics classes (Gunhaart \& Srisawasdi, 2012). In another study, it was determined that learners did experience a realistic process of scientific inquiry with CBL (Russell, Lucas, \& McRobbie, 2004). The question of how VL applications should be used most effectively in science education comes up in research (Moser, Zumbach, \& Deibl, 2017; Rutten et al., 2012). Many researchers have tried to answer such a question with studies focusing on the effects of VL practices on students' 
understanding of scientific concepts and increasing their motivation (Rutten et al., 2012). Some researchers have used simulations to improve the effectiveness of traditional methods (Jimoyiannis \& Komis, 2001), and some have compared the computer methods with traditional methods (Chen \& Howard 2010; Sarı \& Güven 2013). Other researchers used simulations as pre-laboratory activities to increase the effectiveness of laboratory equipment (Zacharia, 2007; Ulukök, Çelik, \& Sarı, 2013). It has also been investigated whether VL can replace traditional laboratories (Finkelstein, Perkins, Adams, Kohl, \& Podolefsky, 2004; Ünlü \& Dökme, 2011). However, there are almost no studies to compare VL and CBL applications. This study compares CBL and VL in terms of the effects on students' graphic skills, attitudes towards physics laboratories and their motivation for science learning

\section{Theoretical background}

Learning physics is considered a challenge for many students who develop a negative attitude towards physics. For this reason, effective physics teaching should encourage learning by developing positive attitudes in students (Sarı, Hassan, Güven, \& Şen, 2017). Such learning occurs when physics teaching focuses on creating interactive learning to facilitate student selfdirection in constructing physical science understandings (Zacharia, 2003). Laboratory activities that enable students to work individually or in groups in physics teaching are very important. Significant laboratory experience is necessary for students to promote, demonstrate and strengthen the concepts of physics (Darrah, Humbert, Finstein, Simon, \& Hopkins, 2014). Laboratory activities enable students to have first-hand experience in seeing how physics laws work. On the other hand, in recent years, with the development of technology, many technology products have taken place both in the laboratory and in the classroom in order to increase the effectiveness of physics teaching. Laboratories are enriched with these technology products and made more modern and technologically equipped than traditional structure. According to Mottmann (1999), the two most important reasons for putting technology and other instructional innovations in physics teaching are improving the physical skills of the students and changing the negative attitudes of the students about physics. Rios and Madhavan (2000) identified four technologies suitable for physics education: (1) computer interface equipment to collect and process data, (2) experimental or theoretical modelling, (3) computer simulations requiring graphics, and (4) research and presentation programs for presenting, reporting and data collection. CBL systems are used to conduct experiments in physics laboratories, to collect and analyse data, to provide graphical systems, and they include technological products such as computer, sensor and timer. CBL experiments have been successfully applied in science and technology schools for decades (Thornton \& Sokoloff, 1990; Steinberg, 2003). Especially, CBL experiments have been developed and applied in the field of physics. Appropriate sensors, interfaces and software have been used to create an effective data collection system for collection, analysis and display of experimental data (Amrani \& Paradis, 2010). Students who experiment on these systems can examine the real-time display of their results and graphics. Thus, interpretation of the data takes place in a very short time. The CBL experiment improves learning by allowing students to perceive the relationship between independent and dependent variable parameters. Discovery with real-time measurements provides feedback and understanding of the subject by presenting the data graphically to the students. It also allows them to predict the relationships between variables and to confirm the nature of these relationships (Trumper \& Gelbman, 2000).

Computer simulations have a special importance in physics teaching and learning. They provide new learning environments that aim to improve the teaching potential of teachers and facilitate active participation of students (Jimoyiannis \& Komis, 2001). Moreover, simulations are realized by presenting dynamic theoretical or simplified models of phenomena or processes 
and encouraging students to observe, discover, reconstruct and instantly receive feedback on objects, events and processes. The simulations allow students to change variables and observe the results to produce scientific results. Simulations can also provide opportunities to visualize dangerous, time-consuming or complex events to interact in class or in the laboratory (McDonald, 2016). The contribution of the simulations to the learning environment and to the learner according to many studies in the literature can be listed as follows (Çelik \& Karamustafaoğlu; Daineko et al., 2017; Jimoyiannis \& Komis, 2001; Mcdonald, 2016; Rutten et al., 2012):

1. Reduces the risk of potential hazards and reduces the economic cost.

2. The virtual laboratory allows the creation of a model for objects, processes and phenomena that cannot be realized in an educational institution or that cannot be actually observed.

3. Virtual laboratory studies are interactive. They can respond to user behaviour in different ways. For example, the weight or drop height of a selected object can only be changed by pointing with a cursor.

4. Virtual laboratories provide an interactive application in accordance with individual learning speed.

5. Virtual laboratory applications provide a variety of experimental materials.

6. It provides an alternative to the cost of creating laboratories in institutions and organizations.

7. It can be easily used individually and collaboratively as a component of a teaching model and method in classroom applications.

8. It provides a safer working environment and data variety by preventing possible data loss.

9. Interfaces and visual interactions in the structure of it contribute to students' affective and cognitive development.

In the physics laboratories, whatever method is used, students are expected to use the skills of observation, hypothesis building and testing, experimenting and making conclusions and comments based on them in the process of conducting scientific experiments. Steps for understanding experimental data are to classify, to establish significant relationships and present them to interested parties. The ability to draw and understand graphics is important here. Because transforming the recorded data into a graph and identifying the relationship between variables as a result of analysing the graph is an important step in reaching the end of the experimental work (Çelik \& Pektaş, 2017; Taşar, Kandil-İngeç \& Ünlü-Güneş, 2002). It is very important for individuals to develop the skills of drawing, understanding and interpreting the graphs which are important in signification of the data. Therefore, this study investigates the development of these skills in students with CBL and VL activities.

\section{Research purposes}

Science laboratories are considered as learning environments where students develop highlevel conceptual learning (Çepni, Kaya, \& Küçük, 2005). In the realization of this conceptual learning, attitude is in the foreground. Attitudes towards science laboratories affect the efficiency of laboratory training (Palic \& Pirasa, 2012). Attitude is also a factor in students' achievements in science (Gonen, 2008; Osborne, Simon, \& Collins, 2003). Studies investigating the impact of the use of technology products such as computer, timer, sensor and simulation on the students' attitudes towards the laboratory in science laboratories should provide more information about the literature. Therefore, the first aim of the study is to 
determine whether the difference between the attitudes of the students using CBL applications and the attitudes of the students who use VL applications is meaningful.

Motivation is another factor that plays an important role in students' learning in science classes (Bonney, Kempler, Zusho et al., 2005). Motivation is an important factor that influences students' learning products (Chen, 2001). Motivation, which tries to explain behaviour and willingness in different activities (Watters \& Ginns, 2000), is an effective force for students to be successful, to study and learn more in school (Martin, 2001). Motivation which has such a significant place in science is also active in physics laboratories. Therefore, the second aim of this study is to determine whether the difference between the motivations of the students using CBL applications and motivations of students using VL applications is significant on learning science.

Graphs are important tools that express the relationships between many physics concepts. Therefore, the ability of students to understand and interpret the relationships between variables in physics concepts directly depends on the degree of comprehension and interpretation of graphs (Demirci \& Uyanık, 2009; Planinic, Milin-Sipus, Katic et al., 2012). Graphical drawings and diagrams support predicting the physical phenomena and understanding abstract concepts (Kozhevnikov, Hegarty, \& Mayer, 2002). Students encounter difficulty using some graphics because of their complex structure, such as in the (a) analysis and interpretation of kinematics graphs representing movement; (b) identification of specific events in velocitytime, acceleration-time, and location-time graphics; and (c) analysis of deceleration and acceleration (Şengel \& Özden, 2010). Although graphics are used as scientific language in science classes, research results show that this language is not used effectively by students (Beichner, 1994). Therefore, VL and CBL applications were used to develop students' skills in drawing, understanding and interpreting graphics. So, another aim of this study is to determine whether there is a significant difference between the students using CBL applications in terms of skills like drawing, understanding and interpreting graphs and the skills of the students using VL applications.

The question underpinning this research is: "Is there a significant difference between CBL applications with air rail test set and VL applications with simulation programs in students' attitudes towards physics laboratory, motivation for science learning and drawing graphs, comprehension and interpretation skills?" Based on this question, the sub-problems of the research were determined as follows:

1. Is there a significant difference between the groups in the attitudes of the students towards the physics laboratory?

2. Is there a significant difference between the groups in the motivation of the students towards science learning?

3. Is there a significant difference between the groups in the students' ability to draw, understand and interpret graphics?

\section{Method}

A semi-experimental method with pre-test, post-test control group was used in the study. Semiexperimental method is a design involving the experimental state which places the samples in control and experiment groups different from a randomly distributed way (Çepni, 2005; Campbell \& Stanley, 1966; Creswell, 2009). Within the scope of the study, experiments were carried out which are related to the laws of motion and collisions in the Curriculum of General Physics Laboratory I of the first semester of the Science Teacher Training Program of the Faculty of Education. The students were divided into two groups. While control group performed these experiments by using the air rail test set, the experimental group performed 
them by using simulation programs. The data of the study were collected via attitude scale towards science laboratory (SLAS), motivation scale for science learning (SLMS) and graph drawing, comprehension and interpretation test (GDCIT) (Table 1).

\section{Table 1: Quasi-experimental design with pre-test and post-test control group}

\begin{tabular}{lllllll}
\hline Groups & pre-test post-test & Model used & Environment & \\
\hline $\begin{array}{l}\text { Experi- } \\
\text { mental }\end{array}$ & & & $\begin{array}{l}\text { VLapplications supported by } \\
\text { simulations }\end{array}$ & $\begin{array}{l}\text { Class (Having a } \\
\text { board) }\end{array}$ & & smart \\
Control & SLAS SLMS GDCIT & & $\begin{array}{l}\text { CBL applications (Air rail } \\
\text { test set) }\end{array}$ & Laboratory (with computer) \\
\hline
\end{tabular}

\section{Study group}

Criteria sampling was used for purposeful sampling methods in this study. The basic of the criteria sampling method is related to the study of all situations that meet a set of predetermined criteria. The mentioned criterion can be created by the researcher or a previously prepared criterion list can be used (Yıldırım \& Şimşek, 2008).

In the selection of the study group to participate in the research, the basic criterion was the students to be the second year students of Science Teacher Training who have succeeded in General Physics 1 course. In accordance with this basic criterion, study has been carried out on the basis of volunteerism with 60 students among the 70 students who are studying in the second grade of education faculty of a university, in Anatolian Turkey. In one of the groups (control group), experiments related to the laws of motion were carried out with CBL (air rail test set) while in the other group (experimental group) the same experiments were carried out with VL applications.

\section{Data collection tools}

The tests applied to the groups as pre-test and post-test were attitude scale, motivation scale, graph drawing, understanding and interpretation test.

SLAS: A 5-point Likert-type scale developed by Nuhoğlu and Yalçın (2004) was used to determine the students' attitudes towards the laboratory and the effect of the teaching materials used in the groups on their attitudes. The scale contains 36 items, and 19 of them are positive and 17 of them are negative. These items were scaled in five categories: "I Participate Totally, Participate, Undecided, I Do Not Participate, and Never Participate". In the scope of the research, the reliability of the scale was reapplied, and the reliability coefficient was calculated as $\alpha=0,92$. After applying the scale, the positive cues were scored as 5, 4, 3, 2, 1 and negative cues as 1, 2, 3, 4, 5 starting from the category "Totally Participating".

SLMS: The motivation scale developed by Dede and Yaman (2008) was used in order to determine the motivation level of the students to learn science and to examine the effect of the teaching materials used in laboratory applications on motivation levels. The response options of the items in the scale are arranged as "I Participate Totally, Participate, Undecided, I Do Not Participate, and Never Participate". As the scores were between 1.00 and 5.00, it was accepted that as the scores got closer to 5.00, the participation level of the students was higher and as the scores got closer to 1.00 it was lower. Materials with a negative sentence root were reversed in the scoring phase. It was determined that the developed test tool had a KMO test result of 0.85 . 
GDCIT: The test developed by Demirci, Karaca and Çirkinoğlu (2006) was used to investigate the effects of the simulation software used in laboratory applications and the computer aided air ray test set on the students' ability to draw, understand and interpret graphics. This test as a whole examines all three sub-skills in one dimension. The test consists of eighteen questions, nine of which are multiple-choice and nine open-ended. Nine multiple-choice questions from these questions were applied to the study group and the Cronbach alpha reliability coefficient of the test was found as $\alpha=0.78$.

\section{Planning and implementation phase of laboratory activities}

In the study, laboratory applications were carried out within the scope of General Physics I (mechanical) subjects. The information on experimental activities is given in Table 2. Experiment manuals containing guidelines for 7 different experiments were distributed to groups, and students completed experimental activities by working in groups of 4-5 people.

\section{Table 2: Information on laboratory activities performed by students}

\begin{tabular}{|c|c|c|}
\hline No & Name of the experiment & Aim of the experiment \\
\hline 1 & $\begin{array}{l}\text { Verification Experiment of Newton's } 1^{\text {st }} \\
\text { Law for Linear Motion }\end{array}$ & $\begin{array}{l}\text { To examine Newton's } 1^{\text {st }} \text { Law for one } \\
\text { dimensional motion }\end{array}$ \\
\hline 2 & $\begin{array}{l}\text { Application of Newton's } 2^{\text {nd }} \text { Law on Air } \\
\text { Rail set }\end{array}$ & $\begin{array}{l}\text { To test the accuracy of Newton's } 2^{\text {nd }} \text { law for } \\
\text { one-dimensional smooth accelerating } \\
\text { motion. }\end{array}$ \\
\hline 3 & $\begin{array}{l}\text { Kinetic Energy of an Object } \\
\text { Accelerating Properly }\end{array}$ & $\begin{array}{l}\text { Draw a time-distance chart for a smooth } \\
\text { accelerating motion. To define kinetic } \\
\text { energy and total energy }\end{array}$ \\
\hline 4 & Flexible Collision in Air Rail Set & $\begin{array}{l}\text { Observation of kinetic energy and } \\
\text { momentum conservation by flexible } \\
\text { collision }\end{array}$ \\
\hline 5 & Inflexible Collision in Air Rail Set & $\begin{array}{l}\text { Observation of kinetic energy and } \\
\text { momentum conservation by inflexible } \\
\text { collision }\end{array}$ \\
\hline 6 & Distance-Velocity Measurements & $\begin{array}{l}\text { Understanding the relationship between } \\
\text { distance and speed, drawing a graph. }\end{array}$ \\
\hline 7 & Distance-Time Measurements & $\begin{array}{l}\text { Draw a distance-time graph of a smoothly } \\
\text { accelerating motion }\end{array}$ \\
\hline
\end{tabular}

\section{VL activities}

The experimental group students used Interactive Physics simulation program to perform experiments (www.design-simulation.com/IP/). This simulation and modelling software is an environment in which almost every physical state can be reconstructed and tracked, and it can provide excellent visual images with numerical, graphical or vector representations (Graham \& Rowlands, 2000). Interactive physic is software that is widely used in the world that can easily develop course material without knowing any programming languages. Especially, it can be used in the field of physics and force-motion issues for creating virtual experiments, problem solving and modelling. In this software, there are simple operations like creating objects, moving objects, applying force, changing the values (mass, position, speed and so on) of 
objects, measuring quantities (energy, position, speed and so on), drawing graphs, adding control buttons for variables and adding menu buttons.

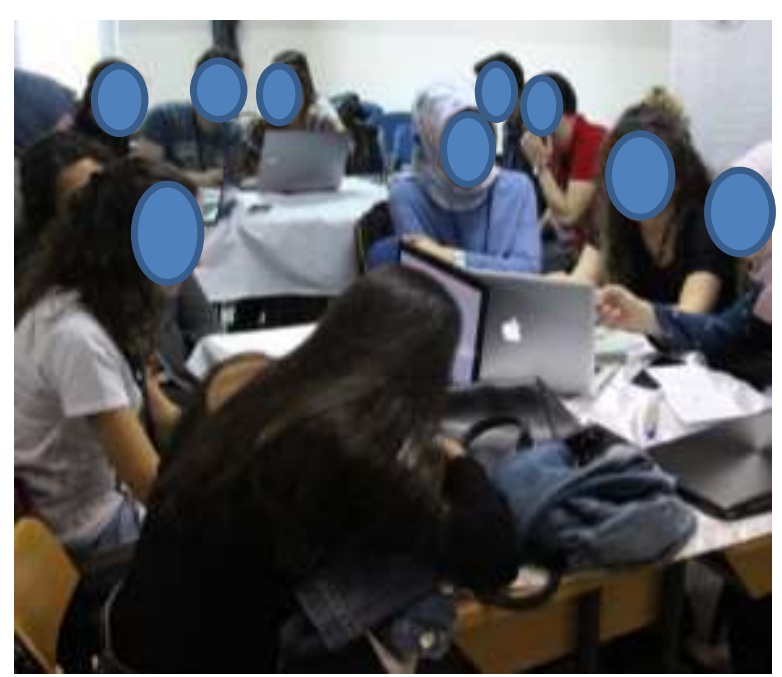

(a)

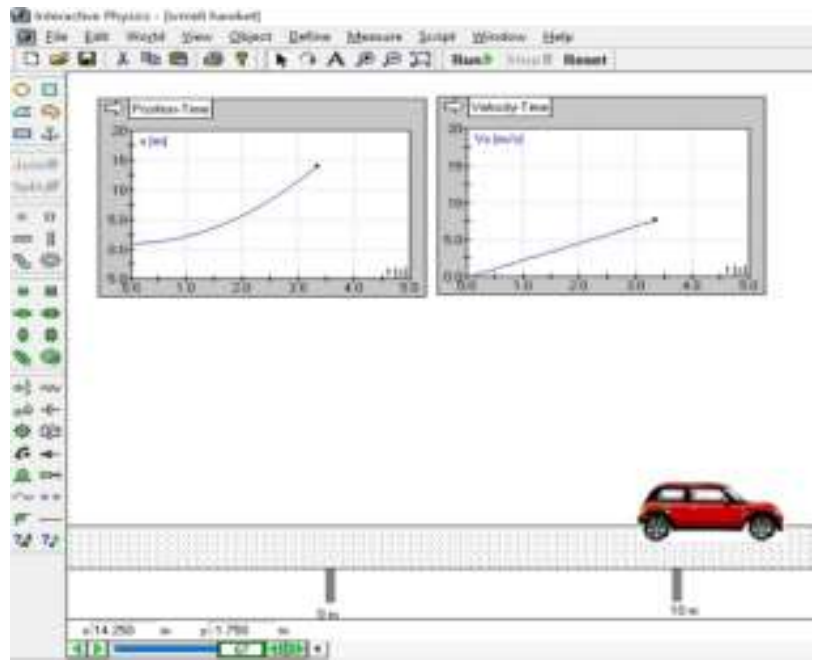

(b)

Figure 1: (a) Students' studies on VL applications (b) Graphical drawings of motion experiment with the use of simulation program

The interactive physics program was introduced to the experimental group, and applications were made during a term. Then, as shown in Fig. 1a, the students were divided into groups of 4-5, and they conducted activities (Table 2) in a collaborative learning environment. Firstly, students in the groups designed experiments according to the guidelines in the experiment manuals. In this design carried out on paper, variables, control parameters, measurement parameters and process steps were determined. Then, a virtual experiment was created by modelling in the program interface. Measurements were taken as graphical representation or numerical values by using the relevant buttons and menus on the program. The data were interpreted, and it was resulted with discussion in the groups. Although these activities were carried out as group work, the students had also opportunity to use the relevant buttons and menus individually by taking into account the importance of the students' interaction with the software. An example of the data generated at the end of the study is given in Fig. 1b.

\section{CBL activities}

The CBL system (air rail set) was first introduced to the control group and its working principle was explained in detail. Then, students were divided into groups of 4-5 students in this study and the experiments given in Table 2 were performed in groups. One of the most important features of the experimental set shown in Fig. $2 \mathrm{a}$ is the ability to connect to a computer. The device that provides this connection is called "Sensor-Cassy". Sensor-Cassy is an arrangement to transfer the movements of the air rail set to the computer. Thus, students can transfer to the computer the data of the experiment on the air rail, and they have a chance to compare theory and practice. As seen in Fig. 2a, students in the groups carry out experiments according to the guidelines in the experiment manuals. First, they set up the experimental setup on the air rail. Then, they started the movement and transferred the data to the computer via the Sensor-Cassy. In the meantime, they collected the data at both numerical values form and a graphical representation. The data were interpreted, and it was resulted with discussion in the groups. As these activities were carried out as group work, each student in the group was allowed to perform the installation of the experiment individually. An example data of the study done by the students is given in Fig. $2 b$. 


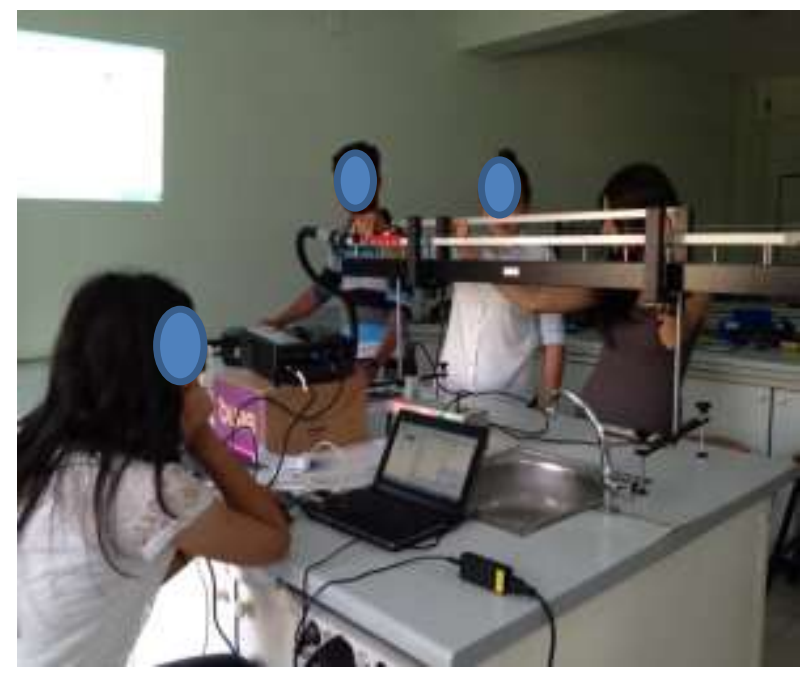

(a)

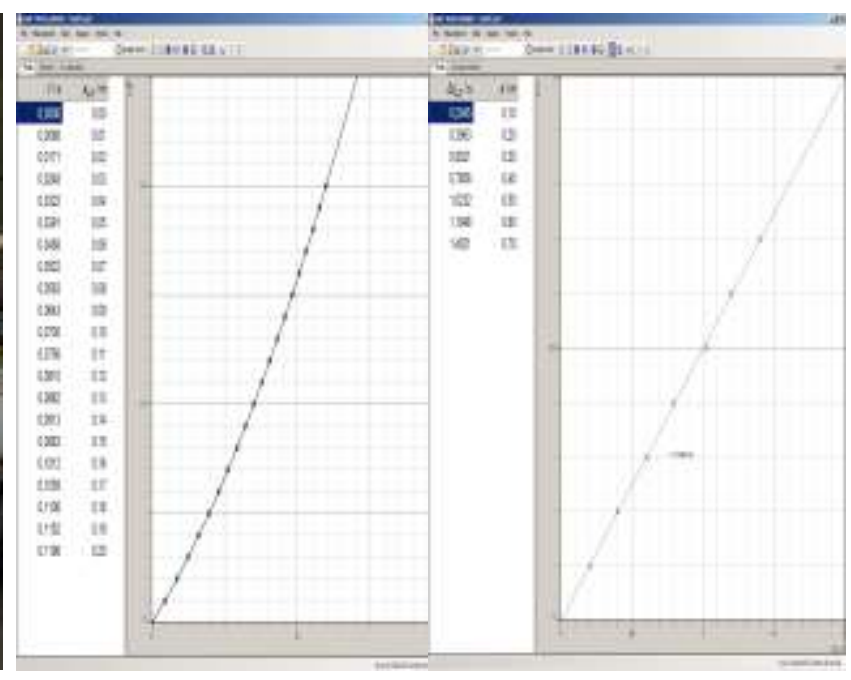

(b)

Figure 2: (a) Students' studies on CBL applications (b) Graphical drawings of motion experiment with the help of Sensor-Cassy

\section{Analysis of data}

Quantitative data from tests and scales were analysed using the SPSS 17 program. Independent group t-test analyses were used to determine whether there was a meaningful relationship between scores of attitude scale, motivation scale and graph drawing, comprehension and interpretation test as pre- and post-test. The significance level between the variables was accepted as $\mathrm{p}<0.05$.

\section{Findings}

Findings and comments on the attitude scale for the physics laboratory

At the beginning there is no significant difference between the control and experimental groups' attitudes for the physics laboratory (Table 3). These findings show that before the study the attitudes of experimental and control groups are equal.

Table 3: Pre-test t test results on Attitude Scale for Physics Laboratory

\begin{tabular}{lllllll}
\hline Groups & $\mathrm{x}$ & $\mathrm{N}$ & $\mathrm{S}$ & $\mathrm{T}$ & $\mathrm{SD}$ & $\mathrm{P}($ significance)* \\
\hline Experimental & 3.75 & 30 & 1.50 & & & \\
Control & 3.81 & 30 & 1.55 & 0.14 & 58 & 0.88 \\
\hline
\end{tabular}

$\mathrm{p}^{*}<0.05$

As seen in Table 4, there was no significant difference between the groups' post-test scores. According to this finding, VL and CBL activities have the same effect on students' attitudes. However, both the test group and the control group seem to increase the post-test mean scores compared to pre-test scores. In particular, the pre-test attitude scores of the control group in which CBL applications were performed were 3.81 and the pos-test score average was 4.37 . In this case, it can be said that both VL and CBL have a positive influence on students' attitudes. 
Table 4: Attitude scale post-test t test results for the physics laboratory

\begin{tabular}{lllllll}
\hline Groups & $\mathrm{x}$ & $\mathrm{N}$ & $\mathrm{S}$ & $\mathrm{T}$ & $\mathrm{SD}$ & $\mathrm{P}$ (significance)* \\
\hline Experimental & 4.04 & 30 & 0.19 & & & \\
Control & 4.37 & 30 & 0.28 & 0.97 & 58 & 0.34 \\
\hline
\end{tabular}

$\mathrm{p}^{*}<0.05$

Findings and comments on the motivation scale for science learning

Before the experiment, the experimental and control groups received science / physics classes in the same way (traditional method). Motivation scales were pre-tested in both groups. According to the results of the independent groups' $t$ test given in Table 5, the point differences between the scores of the control and experiment group motivation scale sub-dimensions obtained in the pre-test were not statistically significant ( $p>0.05)$.

Table 5: Motivation scale for science learning pre-test t-test results

\begin{tabular}{|c|c|c|c|c|c|c|c|}
\hline Scale Factors & Groups & $\mathrm{x}$ & $\mathrm{N}$ & $\mathrm{S}$ & $\mathrm{t}$ & SD & $\mathrm{P}($ significance $) *$ \\
\hline \multirow{2}{*}{ For Research Approach } & Experimental & 23.66 & 30 & 9.82 & \multirow{2}{*}{$\begin{array}{l}- \\
0.46\end{array}$} & \multirow{2}{*}{58} & \multirow{2}{*}{0.65} \\
\hline & Control & 24.50 & 30 & 1.69 & & & \\
\hline \multirow{2}{*}{ For Performance } & Experimental & 19.23 & 30 & 2.52 & \multirow{2}{*}{-} & \multirow{2}{*}{58} & \multirow{2}{*}{0.08} \\
\hline & Control & 20.40 & 30 & 2.67 & & & \\
\hline \multirow{2}{*}{ For Communication } & Experimental & 16.63 & 30 & 1.29 & \multirow{2}{*}{-} & \multirow{2}{*}{58} & \multirow{2}{*}{0.14} \\
\hline & Control & 17.13 & 30 & 1.25 & & & \\
\hline \multirow{2}{*}{ For Collaborative study } & Experimental & 13.50 & 30 & 2.64 & \multirow{2}{*}{$\begin{array}{l}- \\
1.62\end{array}$} & \multirow{2}{*}{58} & \multirow{2}{*}{0.11} \\
\hline & Control & 14.36 & 30 & 1.27 & & & \\
\hline \multirow{2}{*}{ For Participation } & Experimental & 11.30 & 30 & 1.17 & \multirow{2}{*}{$\begin{array}{l}- \\
0.48\end{array}$} & \multirow{2}{*}{58} & \multirow{2}{*}{0.63} \\
\hline & Control & 11.46 & 30 & 1.47 & & & \\
\hline
\end{tabular}

$\mathrm{p}^{*}<0.05$

The Experimental study was started with the pre-test motivation scale for learning science, and CBL applications were done in the control group while VL applications were given in the experimental group. At the end of the study, both groups were subjected to post-test and the findings are given in Table 6. 
Table 6: Motivation scale post-test t-test results for learning science

\begin{tabular}{|c|c|c|c|c|c|c|c|}
\hline Scale Factors & Groups & $\mathrm{x}$ & $\mathrm{N}$ & $S$ & $\mathrm{t}$ & SD & $\mathrm{P}(\text { significance })^{*}$ \\
\hline \multirow{2}{*}{$\begin{array}{l}\text { For Research } \\
\text { Approach }\end{array}$} & Experimental & 25.30 & 30 & 2.38 & \multirow{2}{*}{-0.76} & \multirow{2}{*}{58} & \multirow{2}{*}{0.45} \\
\hline & Control & 25.70 & 30 & 1.62 & & & \\
\hline \multirow{2}{*}{ For Performance } & Experimental & 21.20 & 30 & 2.31 & \multirow{2}{*}{-1.08} & \multirow{2}{*}{58} & \multirow{2}{*}{0.28} \\
\hline & Control & 21.80 & 30 & 1.95 & & & \\
\hline \multirow{2}{*}{$\begin{array}{l}\text { For } \\
\text { Communication }\end{array}$} & Experimental & 18.46 & 30 & 2.13 & \multirow{2}{*}{-3.71} & \multirow{2}{*}{58} & \multirow{2}{*}{0.00} \\
\hline & Control & 20.83 & 30 & 2.76 & & & \\
\hline \multirow{2}{*}{$\begin{array}{l}\text { For Collaborative } \\
\text { study }\end{array}$} & Experimental & 14.73 & 30 & 2.36 & \multirow{2}{*}{-4.10} & \multirow{2}{*}{58} & \multirow{2}{*}{0.00} \\
\hline & Control & 16.87 & 30 & 1.59 & & & \\
\hline \multirow{2}{*}{ For Participation } & Experimental & 13.10 & 30 & 1.60 & \multirow{2}{*}{-3.91} & \multirow{2}{*}{58} & \multirow{2}{*}{0.00} \\
\hline & Control & 14.47 & 30 & 1.04 & & & \\
\hline
\end{tabular}

$\mathrm{p}^{*}<0.05$

According to the motivation scale post-test $\mathrm{t}$ test results for science learning, there are significant differences between the groups in some factors related to scale factors. Significant differences $(p=0.00)$ were found in favour of the control group in communication, cooperative working and participation motivation dimensions. In these sub-dimensions, the importance and achievements of group work come to the forefront when considering the items one by one. It can be considered that the motivation towards communication, collaborative work and participation is not very effective in the simulation software due to the individual interaction of the students. On the other hand, CBL activities are at the forefront of group work because of their content and for this reason cooperation and communication must be at a high level. On the other hand, when Table 5 and Table 6 are compared, it is observed that motivation levels are increased in both groups. In this case, it can be said that CBL and VL applications have a positive effect on the motivation of students to learn science.

Findings and interpretations on graph drawing, understanding and interpretation test As seen in Table 7, there is no significant difference between pre-test $t$ test scores of graph drawing, comprehension and interpretation tests of the study groups before applications. These findings show that before the applications, groups have the same level of drawing, understanding and interpretation levels.

Table 7: Pre-test t-test results for Graph Drawing, Understanding and Interpretation Test

\begin{tabular}{lllllll}
\hline Groups & $\mathrm{x}$ & $\mathrm{N}$ & $\mathrm{S}$ & $\mathrm{t}$ & $\mathrm{SD}$ & $\mathrm{P}($ significance)* \\
\hline Experimental & 14.46 & 30 & 2.88 & & & \\
Control & 15.03 & 30 & 2.55 & 0.80 & 58 & 0.42 \\
\hline
\end{tabular}

$\mathrm{p}^{*}<0.05$ 
Table 8: Post-test t-test results for Graph Drawing, Understanding and Interpretation Test

\begin{tabular}{lllllll}
\hline Groups & $\mathrm{x}$ & $\mathrm{N}$ & $\mathrm{S}$ & $\mathrm{t}$ & $\mathrm{SD}$ & $\mathrm{P}$ (significance)* \\
\hline Experimental & 15.83 & 30 & 3.09 & & & \\
Control & 17.87 & 30 & 3.08 & 2.55 & 58 & 0.01 \\
\hline
\end{tabular}

$\mathrm{p}^{*}<0.05$

Post-test $t$ test results of graph drawing, comprehension and interpretation tests of the study groups are shown in Table 8 . There is a significant difference in the post test scores of the groups in favour of the control group. This result shows that CBL applications improve the ability of students to draw, understand and interpret graphics according to VL applications with simulation software. In addition, when comparing Table 7 and Table 8, it is understood that virtual applications also developed the skills of drawing, understanding and interpreting graphics in students. However, this effect is not as great as CBL applications.

\section{Discussion and conclusion}

In this study, the effects of CBL and VL applications on the students' attitudes towards the physics laboratory, their motivation for learning science, and their ability to draw, understand and interpret the graphic were investigated.

One of the findings of this study is that the CBL and VL applications used in the study groups have a positive effect on students' attitudes towards the physics laboratory. Participants were the first to encounter CBL and VL methods, but they showed a positive attitude towards using these methods in the physics laboratory. One of the important reasons for the students' difficulty in learning physics is to develop a negative attitude toward physics. Therefore, it is important for the methods used in physics teaching to develop positive attitudes in students and to encourage them to learn (Sarı, Hassan, Güven, \& Şen, 2017). Because CBL and VL applications provide significant advantages in physics teaching, they have a positive effect on students' attitude towards physics. In the CBL system, it is thought that students have positive influence on their attitudes towards the physics laboratory by transforming the data into realtime data in a computer environment and interpreting it in a graphical form in a short time (Amrani \& Paradis, 2010). Similarly, in VL applications, it is considered that students develop a positive attitude because of the reasons such as active participation in the learning process, data collection, graphical demonstration, simplifying the learning activities, making the concepts visual and understandable (Chang, Chen, Lin, \& Sung, 2008). It can be said that CBL and VL applications in physics teaching may be effective when it is thought that the attitude displayed against the courses constitutes an important place in shaping the academic achievements of the students (Yaşar \& Anagün, 2008).

When the effects of CBL and VL applications on the motivation of students to learn science were evaluated in the study, it was determined that they had a positive effect on motivation levels in both methods. In support of this finding, both CBL and VL applications were found to be effective on the motivation of learners to learn (Sar1 \& Güven, 2013). According to the results of post-test $t$ test, motivation scale of the study groups showed significant differences in favour of the control group in motivation dimensions for communication, cooperative working and participation. In other words, CBL applications have become more effective in increasing students' motivation levels for communication, cooperative work and participation 
than VL applications. This can be considered as a result of the effective implementation of teamwork and cooperation in CBL applications. According to the literature, the students, who think that the contributions of team members and their interaction add value to their education, are indicated that they enjoy more and learning occurs with increasing levels of motivation (Gomez, Wu, \& Passerini, 2010). In VL applications, although they work as a group, it can be considered that the individual interaction of students is not very effective in providing motivation for communication, cooperation and participation

While a significant difference was found between the post-test scores in favour of the control group, there was no significant difference between the pre-test scores of the graph drawing, comprehension and interpretation tests of the study groups. This result suggests that CBL applications are more effective in the development of students' ability to draw, understand and interpret graphics than VL applications. The implementation of the CBL experiments requires students several advantages like real-time data collection and graphical display. Thanks to these advantages, students can interpret the data in a short time (Amrani \& Paradis, 2010). Students receive instant feedback by the graphics in real time from the displayed data. Rapid visualization of the data allows modification of experimental parameters within a reasonable time. These advantages are thought to be beneficial in the development of graphical skills. On the other hand, when the graphical skills of the experimental group were compared with the pre-test and post-test point average, it was observed that VL applications also improved the skills of drawing, understanding and interpreting graphics. The graphical representation of the interactive physics program used in this study is quite good (Graham \& Rowlands, 2000). Students have converted the virtually obtained data into graphical form using appropriate buttons and menus. According to the literature, computer simulations are good tools for improving students' graphic interpretation skills (Sahin, 2006). However, this study shows that CBL applications are more effective in the development of graphical skills than VL applications. If the students of experiment group could not learn the simulation program sufficiently, they could be challenged to design virtual experiments using the software and to obtain data and graphical representations. Thus, students may have spent most of their time using the software. In order to avoid such a problem, students should be taught the simulation program adequately and the practices should be made. In the present study, this process may be insufficient. On the other hand, it is not considered that this kind of problem has been encountered in the CBL applications. Students performing CBL experiments did not encounter any difficulties in using various probes, interfaces and software. Most of the lab time was spent observing, interpreting, discussing and analysing physical phenomena (Carlson, Igglund, \& Bernhard, 1998). Therefore, it was quite easy to display experimental results, create graphs and use existing function tools that match the measured values.

Within the scope of the research, university students 'attitude, motivation and graphing, understanding and interpreting skills in favour of the control group can be related to the students' interaction with the materials in the learning process. Indeed, the need for a learning environment to interact with all sense organs is likely to positively affect learning products. In the study, students performed CBL applications using experimental equipment in real laboratory environment. Researches have proven that an approach that combines real and virtual experiences gives the best results. Students should train themselves in practical and motor skills and gain practical experience with physical equipment to specialize in experimental procedures and learn science content (De Jong, Linn, \& Zacharia, 2013). By integrating the training technology into the real laboratory environment, students can optimize their learning (De Jong et al., 2013; Lui \& Slotta, 2013). In sum, education technology should not completely separate students from the real laboratory environment and equipment. 


\section{Acknowledgement}

This study was supported as Scientific Research Project of Kırıkkale University, coded as 2011/078.

\section{References}

Akçayır, M., Akçayır, G., Pektaş, H. M., \& Ocak, M. A. (2016). Augmented reality in science laboratories: The effects of augmented reality on university students' laboratory skills and attitudes toward science laboratories. Computers in Human Behavior, 57, 334-342.

Amrani, D., \& Paradis, P. (2010). Use of computer-based data acquisition to teach physics laboratories: case study-simple harmonic motion. Latin-American Journal of Physics Education, 4(3), 511-514.

Azar, A., \& Şengüleç, Ö. A. (2011). Computer-Assisted and Laboratory-Assisted teaching methods in physics teaching: The effect on student physics achievement and attitude towards physics. Eurasian Journal of Physics \& Chemistry Education, 3(1), 43-50.

Beichner, R. J. (1990). The effect of simultaneous motion presentation and graph generation in a kinematics lab. Journal of Research in Science Teaching, 27(8), 803-815. doi:10.1002/tea.3660270809.

Berrett, D. (2012). How 'flipping' the classroom can improve the traditional lecture. The Chronicle of Higher Education, 12(19), 1-3.

Bonney, C. R., Kempler, T. M., Zusho, A., Coppola, B. P., \& Pintrich, P. R. (2005). Student learning in science classrooms: What role does motivation play? In W.W. Cobern et al. (Eds) Beyond Cartesian dualism (pp. 83-97), Science \& Technology Education Library, Vol 29. Springer: Dordrecht.

Bozkurt, E. (2008). Fizik eğitiminde hazırlanan bir sanal laboratuvar uygulamasının öğrenci başarısına etkisi (Doctoral dissertation, Selçuk Üniversitesi Fen Bilimleri Enstitüsü).

Campbell, D. T., \& Stanley, J. C. (1966). Experimental and quasi experimental designs for research. Chicago: Rand McNally \& Company.

Carlson H., Igglund R., \& Bernhard J. (1998). Implementing computer based lab work in Physics. International Conference Practical Work in Science Education, Copenhagen, 20 - 23 May.

Chang, K. E., Chen, Y. L., Lin, H. Y., \& Sung, Y. T. (2008). Effects of learning support in simulation-based physics learning. Computers \& Education, 51(4), 1486-1498.

Chen, A. (2001). A theoretical conceptualization for motivation research in physical education: An integrated perspective. Quest, 53(1), 35-58.

Chen, C. H., \& Howard, B. (2010). Effect of live simulation on middle school students' attitudes and learning toward science. Educational Technology \& Society, 13(1), 133-139.

Chiu, J. L., DeJaegher, C. J., \& Chao, J. (2015). The effects of augmented virtual science laboratories on middle school students' understanding of gas properties. Computers \& Education, 85, 59-73.

Creswell, J. W. (2009). Research design: Qualitative, quantitative, and mixed methods approaches (3rd ed.). Thousand Oaks, CA: Sage.

Çelik, H., \& Karamustafaoğlu, O. (2016). Science prospective teachers' self-efficacy and views on the use of information technologies in the teaching of physics concepts. Necatibey Faculty of Education Electronic Journal of Science \& Mathematics Education, 10(1), 182-208.

Çelik, H., \& Pektaş, H. M. (2017). Graphic comprehension and interpretation skills of preservice teachers with different learning approaches in a technology-aided learning environment. International Journal of Science and Mathematics Education, 15(1), 1-17.

Çepni, S. (2005). Araştırma Ve Proje Çalışmalarına Giriş. İkinci Baskı, Üçyol Kültür Merkezi, Trabzon.

Çepni, S., Kaya, A., \& Küçük, M. (2005). Determining the physics teachers' in-service needs for laboratories. $J$. Turkish Educ. Sci, 3(2), 181-194.

Daineko, Y., Dmitriyev, V., \& Ipalakova, M. (2017). Using virtual laboratories in teaching natural sciences: An example of physics courses in university. Computer Applications in Engineering Education, 25(1), 39-47.

Darrah, M., Humbert, R., Finstein, J., Simon, M., \& Hopkins, J. (2014). Are virtual labs as effective as hands-on labs for undergraduate physics? A comparative study at two major universities. Journal of Science Education and Technology, 23(6), 803-814.

Dede, Y., \& Yaman, S. (2008). A questionnaire for motivation toward science learning: A validity and reliability study. Necatibey Faculty of Education Electronic Journal of Science and Mathematics Education, 2(1), 19-37.

De Jong, T., Linn, M. C., \& Zacharia, Z. C. (2013). Physical and virtual laboratories in science and engineering education. Science, 340(6130), 305-308.

Demirci, N., Karaca, D., \& Çirkinoğlu, A. G. (2006). Üniversite öğrencilerinin grafik anlama ve yorumlamaları ile kinematik başarıları arasındaki ilişki. VII. Ulusal Fen Bilimleri ve Matematik Eğitimi Kongresi, Gazi Üniversitesi, Gazi Ĕ̈itim Fakültesi, 7-9.

Demirci, N., \& Uyanık, F. (2009). The correlation between tenth grade students' understanding and interpreting graphs and their kinematics achievement. Necatibey Faculty of Educ. Elect. J. Sci. Math. Educ, 3(2), 22-51. 
Duman, M. Ş., \& Avcı, G. (2016). Sanal laboratuvar uygulamalarının öğrenci başarısına ve öğrenilenlerin kalıcılığına etkisi. Erzincan Üniversitesi Ĕ̆itim Fakültesi Dergisi, 18(1), 13-33.

Finkelstein, N. D., Perkins, K. K., Adams, W., Kohl, P., \& Podolefsky, N. (2004). Can computer simulations replace real equipment in undergraduate laboratories? Department of Physics: University of Colorado, Boulder.

Gomez, E. A., Wu, D., \& Passerini, K. (2010). Computer-supported team-based learning: The impact of motivation, enjoyment and team contributions on learning outcomes. Computers \& Education, 55(1), 378390.

Gonen, S. (2008). A study on student teachers' misconceptions and scientifically acceptable conceptions about mass and gravity. Journal of Science Education and Technology, 17(1), 70-81.

Graham, T., \& Rowlands, S. (2000). Using computer software in the teaching of mechanics. International Journal of Mathematical Education in Science and Technology, 31(4), 479-493.

Gunhaart, A., \& Srisawasdi, N. (2012). Effect of integrated computer-based laboratory environment on students' physics conceptual learning of sound wave properties. Procedia-Social and Behavioral Sciences, 46, 57505755.

Jaakkola, T., \& Nurmi, S. (2008). Fostering elementary school students' understanding of simple electricity by combining simulation and laboratory activities. Journal of Computer Assisted Learning, 24(4), 271-283.

Jaakkola, T., Nurmi, S., \& Veermans, K. (2011). A comparison of students' conceptual understanding of electric circuits in simulation only and simulation-laboratory contexts. Journal of Research in Science Teaching, 48(1), 71-93.

Jimoyiannis, A., \& Komis, V. (2001). Computer simulations in physics teaching and learning: A case study on students' understanding of trajectory motion. Computers and Education, 36(2), 183-204.

Kaberman, Z., \& Dori, Y. J. (2009). Question posing, inquiry and modeling skills of chemistry students in the case-based computerized laboratory environment. International Journal of Science and Mathematics Education, 7, 597-625.

Klahr, D., Triona, L. M., \& Williams, C. (2007). Hands on what? The relative effectiveness of physical versus virtual materials in an engineering design project by middle school children. Journal of Research in Science Teaching, 44(1), 183-203.

Kozhevnikov, M., Hegarty, M. \& Mayer, R. (2002). Spatial abilities in problem solving in kinematics. In M. Anderson, B. Meyer \& P. Olivier (Eds.), Diagrammatic representation and reasoning (pp. 155-171). London, England: Springer.

Liu, C., Wu, C., Wong, W., Lien, Y. \& Chao, T. (2017). Scientific modeling with mobile devices in high school physics labs. Computers and Education, 105, 44-56.

Lui, M. \& Slotta, J. D. (2013). Exploring evolutionary concepts with immersive simulations. In N. Rummel, M. Kapur, M. Nathan, \& S. Puntambekar (Eds.) (2013). To See the World and a Grain of Sand: Learning across Levels of Space, Time, and Scale: CSCL 2013 Conference Proceedings Volume 1 - Full Papers \&Symposia. International Society of the Learning Sciences. pp. 304-311.

Martin, A. J. (2001). The student motivation scale: A tool for measuring and enhancing motivation. Australian Journal of Guidance and Counselling, 11, 11-20.

Moser, S., Zumbach, J., \& Deibl, I. (2017). The effect of metacognitive training and prompting on learning success in simulation-based physics learning. Science Education, 101(6), 944-967.

Mcdonald, C. V. (2016). STEM education: A review of the contribution of the disciplines of science, technology, engineering and mathematics', Science Education International, 27, 4, 530-569.

Mottmann, J. (1999). Innovations in physics teaching. The Physics Teacher, 37, 74-77.

Nuhoğlu, H., \& Yalçın, N. (2004). The development of attitude scale for physics laboratory and the assessment of pre-service teachers' attitudes towards physics laboratory. Gazi University Kırsehir Faculty of Education Journal, (5), 317-327.

Olympiou, G., \& Zacharias, Z. (2013). Making the invisible visible: Enhancing students' conceptual understanding by introducing representations of abstract objects in a simulation. Instructional Science, 41(3), 575-596.

Osborne, J., Simon, S., \& Collins, S. (2003). Attitudes towards science: A review of the literature and its implications. International Journal of Science Education, 25(9), 1049-1079.

Palic, G., \& Pirasa, N. (2012). A study of pre-service teachers' tendency for imprudent behaviour and physics laboratory attitudes. Procedia-Social and Behavioral Sciences, 47, 823-828.

Planinic, M., Milin-Sipus, Z., Katic, H., Susac, A., \& Ivanjek, L. (2012). Comparison of student understanding of line graph slope in physics and mathematics. International Journal of Science and Mathematics Education, 10(6), 1393-1414.

Rios, J., \& Madhavan, S. (2000). Guide to adopting technology in the physics classroom. The Physics Teacher, 38, 94-97. 
Russell, D. W., Lucas, K. B., \& McRobbie, C. J. (2004). Role of the microcomputer-based laboratory display in supporting the construction of new understandings in thermal physics. Journal of Research in Science Teaching, 41(2), 165-185.

Rutten, N., Van Joolingen, W. R., \& Van der Veen, J. T. (2012). The learning effects of computer simulations in science education. Computers and Education, 58, 136-153.

Rutten, N., Van der Veen, J. T., \& Van Joolingen, W. R. (2015). Inquiry-based whole-class teaching with computer simulations in physics. International Journal of Science Education, 37(8), 1225-1245.

Sahin, S. (2006). Computer simulations in science education: Implications for distance education. Online Submission, 7(4).

Sar1, U., \& Güven, G. B. (2013). The effect of interactive whiteboard supported inquiry- based learning on achievement and motivation in physics and views of prospective teachers towards the instruction. Necatibey Faculty of Education Electronic Journal of Science and Mathematics Education, 7(2), 93-125.

Sarı, U., Hassan, A. H., Güven, K., \& Şen, Ö. F. (2017). Effects of the 5E teaching model using interactive simulation on achievement and attitude in physics education. International Journal of Innovation in Science and Mathematics Education (formerly CAL-laborate International), 25(3), 20-35.

Smetana, L. K., \& Bell, R. L. (2012). Computer simulations to support science instruction and learning: A critical review of the literature. International Journal of Science Education, 34(9), 1337-1370.

Steinberg, R. (2003). Effect of computer-based laboratory instruction on future teachers' understanding of nature of science. Journal of Computers in Mathematics and Science Teaching, 22, 185-205.

Şengel, E., \& Yaşar Özden, M. (2010). The effects of computer simulated experiments on high school students' understanding of the displacement and velocity concepts. Eurasian Journal of Educational Research (EJER), (39).

Taşar, M. F., Kandil-İngeç, S., \& Ünlü-Güneş, P. (2002). Grafik çizme ve anlama becerisinin saptanması [Measuring students' skills of drawing and understanding graphs]. Poster session presented at the Fifth National Congress of Science and Mathematics Education. Ankara, Turkey: Middle East Technical University.

Thornton, R. C., \& Sokoloff, D. R. (1990). Learning motion concepts using real-time microcomputer-based laboratory tools. Am. J. Phys., 58, 858-867.

Tortosa, M. (2012). The use of microcomputer based laboratories in chemistry secondary education: Present state of the art and ideas for research-based practice. Chemistry Education Research and Practice, 13(3), 161-171.

Trumper, R., \& Gelbman, M. (2000). Investigating electromagnetic induction trough a minicomputer-based laboratory, Phy. Educ., 35, 90-95.

Trundle, K. C., \& Bell, R. L. (2010). The use of a computer simulation to promote conceptual change: a quasiexperimental study. Computers \& Education, 54(4), 1078-1088.

Ulukök, Ş., Çelik, H., \& Sarı, U. (2013). The effects of computer-assisted instruction of simple circuits on experimental process skills. Journal of Theoretical Education Science, 6(1), 77-101.

Uşun, S. (2004). Bilgisayar destekli ögretimin temelleri [Foundations of computer assisted instruction]. Ankara, Turkey: Nobel Yayıncilik.

Ünlü, Z. K., \& Dökme, İ. (2011). The effect of combining analogy-based simulation and laboratory activities on Turkish elementary school students' understanding of simple electric circuits. Turkish Online Journal of Educational Technology, 10(4), 320-329.

Yaşar, Ş., \& Anagün, Ş. S. (2008). İlköğretim beşinci sınıf fen ve teknoloji dersi tutum ölçeğinin güvenirlik ve geçerlik çalışmaları. Anadolu Üniversitesi Sosyal Bilimler Dergisi, 8 (2), 223-234.

Yıldırım, A., \& Şimşek, H. (2008). Nitel araştırma yöntemleri.(7. Baskı). Ankara: Seçkin Yayıncılık.

Watters, J. J., \& Ginns, I. S. (2000). Developing motivation to teach elementary science: Effect of collaborative and authentic learning practices in preservice education. Journal of Science Teacher Education, 11(4), 301321.

Wiesner, T. F., \& Lan, W. (2004). Comparison of student learning in physical and simulated unit operations experiments. Journal of Engineering Education, 93, 195-204.

Wu, W., Chang, H. P., \& Guo, C. J. (2009). The development of an instrument for a technology-integrated science learning environment. International Journal of Science and Mathematics Education, 7(1), $207-233$. doi:10.1007/s10763-007-9116-5.

Zacharia, Z. C. (2003). Beliefs, attitudes, and intentions of science teachers regarding the educational use of computer simulations and inquiry-based experiments in physics. Journal of Research in Science Teaching, 40(8) $792-823$.

Zacharia, Z. C. (2007). Comparing and combining real and virtual experimentation: An effort to enhance student's conceptual understanding of electric circuits. Journal of Computer Assisted Learning, 23(2), 120132. 
International Journal of Innovation in Science and Mathematics Education, 27(1), 1-17, 2019

Zhang, X., De Pablos, P. O., \& Xu, Q. (2014). Culture effects on the knowledge sharing in multi-national virtual classes: A mixed method. Computers in Human Behaviour, 31, 491-498. 